\title{
Treating sunflower seeds subjected to ozonization ${ }^{1}$
}

\author{
Vitor Oliveira Rodrigues ${ }^{2}$, Fabiano Ramos $\mathrm{Costa}^{2}$, Marcela Carlota Nery², \\ Sara Michelly Cruz ${ }^{2 *}$, Soryana Gonçalves Ferreira de $\mathrm{Melo}^{2}$, Maria Laene \\ Moreira de Carvalho ${ }^{3}$
}

\begin{abstract}
Sunflower crops (Helianthus annuus L.) are a source of pathogens that can be transmitted by means of the seeds. An alternative for the treatment of seeds can be the application of an ozone compound, which has been used in various segments to eliminate microorganisms. Three lots of the Embrapa 122 variety have been used to assess the efficacy of ozone to control pathogens in sunflowers seeds. To typify the profile of the lots we have determined the moisture content, the first germination counting, the germination, the germination speed index, emergence, initial stand, emergence speed index and health. The lots have been stored in an ozone-rich environment for periods of 20, 60 and 120 minutes and without ozone (control). After the treatments, the seeds were tested to assess their health and physiological quality through the said tests as well as a test for accelerating aging, tetrazolium and incidence and severity of fungi. It has been concluded that the treatment for $H$. annuus seeds, Embrapa 122 variety, with ozone concentration of $1741 \mathrm{ppmv}(0.24 \mathrm{~g} / \mathrm{h})$, for 60 minutes, reduces the fungal presence of Alternaria sp., Fusarium sp., Aspergillus sp. and Penicillium sp. without affecting their physiological potential.
\end{abstract}

Index terms: Helianthus annuus, vigor, viability, health, ozone.

\section{Tratamento de sementes de girassol submetidas à ozonização}

\begin{abstract}
RESUMO - A cultura do girassol (Helianthus annuus L.) é hospedeira de inúmeros patógenos que podem ser transmitidos via sementes. Uma alternativa para o tratamento das sementes pode ser a aplicação de ozônio composto que tem sido usado em diversos segmentos na eliminação de microrganismos. Para avaliar a eficiência do ozônio no controle de patógenos em sementes de girassol foram utilizados três lotes da cultivar Embrapa 122. Para caracterização do perfil dos lotes determinouse o grau de umidade, a primeira contagem de germinação, germinação, índice de velocidade de germinação, emergência, estande inicial, índice de velocidade de emergência e sanidade. Os lotes foram mantidos em ambiente rico em ozônio pelos períodos de 20, 60 e 120 minutos e sem ozônio (controle). Após os tratamentos as sementes foram submetidas à avaliação da qualidade fisiológica e sanitária, por meio dos testes já mencionados, além dos testes de envelhecimento acelerado, tetrazólio e incidência e severidade de fungos. Concluiu-se que o tratamento de sementes de H. annuus, cultivar Embrapa 122, com ozônio na concentração de 1741 ppmv $(0.24 \mathrm{~g} / \mathrm{h})$, por 60 minutos, reduz a população fúngica de Alternaria sp., Fusarium sp., Aspergillus sp. e Penicillium sp. sem afetar o seu potencial fisiológico.
\end{abstract}

Termos para indexação: Helianthus annuus, vigor, viabilidade, sanidade, ozônio.

\section{Introduction}

Helianthus annuus L. belongs to the Asteraceae family. It is an annual dicotyledonous and it is used as animal feed, production of oil for human consumption and biodiesel production (Porto et al., 2007).

The spread of $H$. annuus is essentially seminiferous and it is important to use high quality seeds to obtain high productivity. According to Gomes et al. (2006), the spread of H. annuus culture

${ }^{1}$ Submitted on 4/16/2015. Accepted for publication on 7/22/2015.

${ }^{2}$ Departamento de Agronomia, Universidade Federal dos Vales do Jequitinhonha e Mucuri, 39100-000 - Diamantina, MG, Brasil. can be hampered by the seeds low physiological and health quality. Most of the etiologic disease agents is transmitted by seeds, especially those caused by fungi that reduce germination power and can be disseminated by establishing primary infestation focuses on growing areas (Machado, 1994).

The control of diseases and pests in agriculture, including the control of pathogens in seeds, is accomplished primarily by means of synthetic products that generate high costs and environmental and toxicological risks (Campanhola and Bettiol, 2003).

${ }^{3}$ Departamento de Agricultura, Universidade Federal de Lavras, Caixa Postal 3037, 37200-000 - Lavras, MG, Brasil.

*Corresponding author <saramichellycruz@gmail.com> 
As an alternative to chemicals, ozone has been used to control insect pests and fungi in stored grains (Mendez et al., 2003; Pereira et al., 2008), in postharvest fruits (Simão and Rodríguez, 2008), in minimally processed fruits (Ponce et al., 2010), in food ripening rooms (Pinto et al., 2007; Serra et al., 2003), and in the degradation of mycotoxins (Akbas e Ozdemir, 2006). An advantage is the possibility of being produced at the site of use and not requiring special packaging and transport of goods for the treatment (Mendez et al., 2003).

The effects of seeds exposure to ozone have been studied and a method that benefits the seed germination has been patented by Yvin and Coste (1995), and the another one by Klaptchuk (2004) to sterilize the seeds and degrade residual herbicides with use of ozone. It has been found that exposure to ozone favors the acceleration of tomato seed germination by breaking dormancy (Sudhakar et al., 2011); however, according to $\mathrm{Wu}$ et al. (2006) the prolonged exposure to gas can reduce the germination of wheat seeds. Studies by Violleau et al. (2008) have suggested that long periods of ozonization may be harmful for the quality of the seeds; however, which would a long period be has not been specified.

Given the potential of ozone use in the inactivation of fungi and the little knowledge about its effects on germination, the aim of this study was to verify the effectiveness of ozone use in the control of plant phytopathogens and its possible effects on seed physiological quality of $H$. annuus.

\section{Material and Methods}

Three lots of Helianthus annuus L. seeds from cultivar Embrapa 122 were used, acquired from the seed bank at "Embrapa Produtos e Mercado", harvested in the Brazilian city of Dourados, MS, 2013 harvest. These lots were ranked by sieve screen, with lot 1 of $3.5 \mathrm{~mm}$ small sieve, lot 2 of 4.0 $\mathrm{mm}$ average sieve and lot 3 of $5.5 \mathrm{~mm}$ large sieve, so as to ensure greater uniformity of the gas passage by the seeds.

The seeds were kept in a rich atmosphere in ozone by periods of 20, 60 and 120 minutes and without ozonization (control). Soon after, determinations and physiological and health tests were carried out.

Equipment to apply the ozone treatment: ozone was obtained by means of the Electrochemical Ozone Generator (Gerador de Ozônio Eletroquímico) which is under patent Leonardo and Jardim, 2011 F. "Gerador de Ozônio Eletroquímico - INPI - PI1101892-5.2011, Brasil.” The seeds were placed in a continuous flow chamber made with a PVC (polyvinyl chloride) pipe, which has a valve at each end; inside the tube the seeds were placed on individual cage rings in a single layer to avoid overlapping seeds, ensuring the contact of ozone with all of them (Figure 1). The ozone concentrations were measured directly by means of a spectrophotometer attached to the apparatus throughout the ozonization period, thus evaluating the average ozone concentration in each tested period. The average production of ozone in the ozonization time interval for the three periods (20 minutes, 60 minutes and 120 minutes) was 1741 ppmv (parts per million by volume) and $0.24 \mathrm{~g} / \mathrm{h}$.

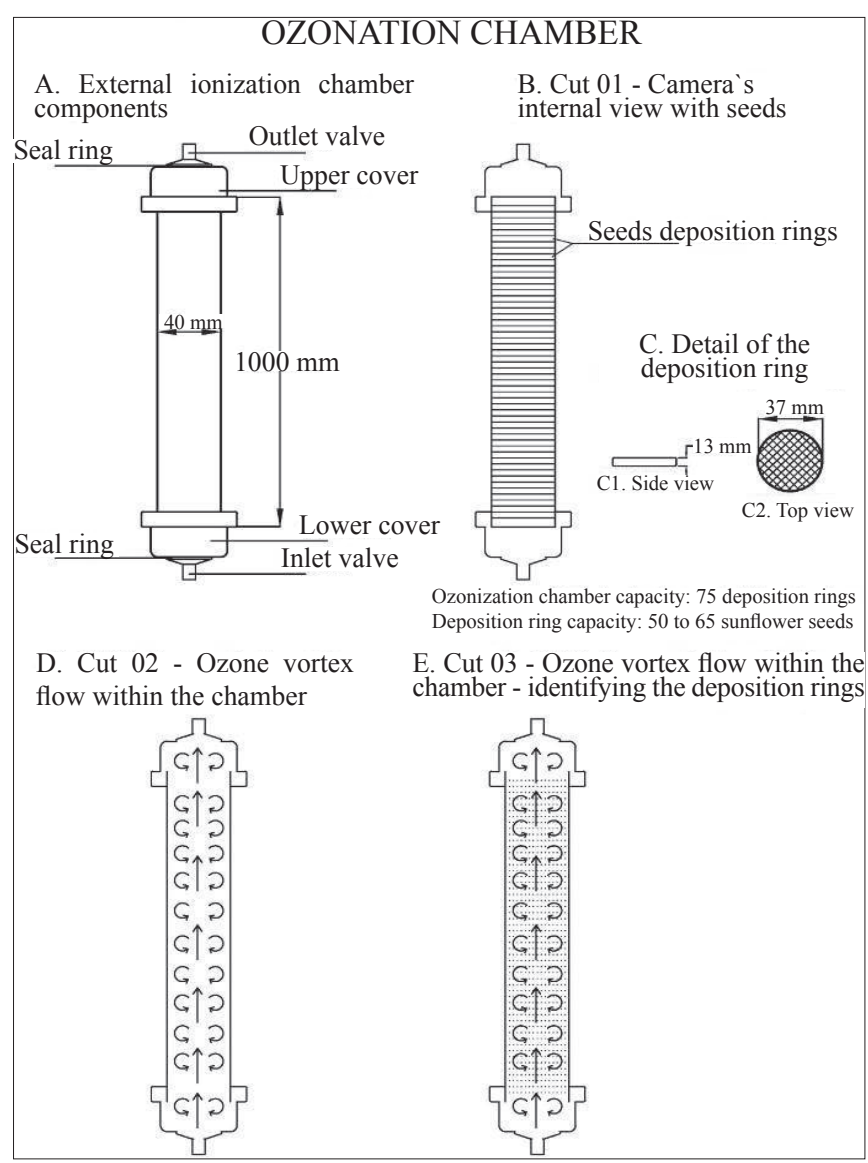

Figure 1. Outline of the ozonization chamber.

The characterization of the lots was carried out by determining the moisture content $(\mathrm{M})$, first germination counting (FGC), germination $(\mathrm{G})$, germination speed index (GSI), emergence (E), initial stand (IS) emergence speed index (ESI) and health. The moisture content was determined by the oven method at $105{ }^{\circ} \mathrm{C}$ for 24 hours (Brasil, 2009b).

The following tests were carried out with four repetitions of 50 seeds per lot.

Germination test: roll paper substrate was used at a constant temperature of $25{ }^{\circ} \mathrm{C}$ and a 12-hour photoperiod. Evaluations were performed on the fourth day, first germination counting, and on the tenth day, final counting (Brasil, 2009b). The germination speed index (GSI) was calculated using the 
formula proposed by Maguire (1962).

Seedling emergence test: they were seeded in plastic boxes containing earth and sand in the ratio $2: 1$, with the substrate sterilized and moistened with distilled water, and the boxes kept in a growth room at $25{ }^{\circ} \mathrm{C}$ with constant photoperiod. Evaluations of the number of seedlings emerged from the initial stand were held at four days and of the final stand at ten days after sowing. The results were expressed in percentage. For the emergence speed index (ESI), the number of emerged seedlings was daily computed from the beginning of the emergence and the calculation was performed according to Maguire (1962).

Health test: the lots were divided into ten replicates of 20 seeds. The method of the blotter paper in gerbox box was used, with a thin layer of agar-agar at $1.0 \%$. The blotter papers were moistened with distilled water and 2,4-dichlorophenoxyacetic acid. The test was associated with the freezing method (Goulart, 2009). The gerboxes with the seeds were incubated under white fluorescent light bulbs and a 12-hour photoperiod for seven days at a temperature of $20^{\circ} \mathrm{C}$ (Brasil, 2009a). After the incubation period, the seeds were individually analyzed in a stereoscopic magnifier and optical microscope for the identification and quantification of fungi. The results were expressed as percentage of infected seeds, by computing the incidence of the fungus.

After the treatments with ozone, the lots were submitted to the germination tests, first germination counting, GSI, emergence, ESI and health, as described above, and by the accelerated aging and tetrazolium tests.

Accelerated aging test: 50 seeds from each lot and each treatment were placed on an aluminum screen inside a gerbox plastic box with $40 \mathrm{~mL}$ of distilled water at the bottom, at $42{ }^{\circ} \mathrm{C}$ for 72 hours (Aguiar et al., 2001). After this period, the germination test was performed as previously described.

Tetrazolium test: 50 seeds from each lot and each treatment were placed to soak on paper for 16 hours in a B.O.D. (Biochemical Oxygen Demand)-type germination chamber at $25^{\circ} \mathrm{C}$. Subsequently to the removal of the pericarp and the integument, the seeds were then placed to soak in tetrazolium solution at the concentration of $0.5 \%$ and packed in B.O.D. at $30{ }^{\circ} \mathrm{C}$ for one hour (Brasil, 2009b). After color development, the percentage of viable, unviable and vigorous seeds were evaluated.

To assess the ozone potential as a method of disinfection of $H$. annuus seeds, the tests described below were performed.

Infestation severity index (ISI): a grading scale based on the percentage of each seed covered by typical surface structures of fungi was defined, attributing grades (0) for the absence of fungal structures, (1) for up to $25 \%$ of the seed covered by fungal structures, (2) for up to $50 \%$ of the seed covered by fungal structures, (3) for up to $75 \%$ of the seed covered by fungal structures, and (4) for more than $75 \%$ of the seed covered by fungal structures. This analysis was performed along the health check.

To determine the seed infestation severity index, an adaptation of a methodology proposed by McKinney (1923) was used.

$$
\mathrm{ISI}=\mathrm{ISI}=\frac{\sum(\mathrm{f} \times \mathrm{n}) \times 100}{\mathrm{~F} \times \mathrm{N}}
$$

Where:

(ISI): infestation severity index by seed evaluated; (f): a grade of scale attributed to the evaluated seed; (n): number of seeds which have received the grade; $(\mathrm{F})$ : maximum scale grade, and $(\mathrm{N})$ : total number of seeds evaluated by replicate.

The experiment was conducted in a completely randomized design with four replications, and the analyses of variance were performed using the statistical software SISVAR (Ferreira, 2011). The data were transformed into arcsin to approach the normal curve and subjected to analysis of variance and the averages compared by Scott-Knott test at $5 \%$ probability.

\section{Results and Discussion}

The lots showed good physiological quality before being ozonized (Table 1). The germination of all the $H$. annuus seeds lots was in accordance with the marketing standard in Brazil for S1 and S2 seeds, which is $70 \%$ (Brasil, 2013), and the water content was within the range for storage, transport and marketing, ranging from 5\% to $10 \%$, according to Leite et al. (2005) and showed no statistical differences.

For the germination test, first germination counting, GSI, emergence and ESI (Table 1) it was observed that there were no significant differences among the lots. In the case of the initial stand, the greatest vigor was observed for lot 2 in relation to the other lots.

A higher percentage of emergence compared to the germination test was observed (Table 1). This fact can be explained by the health quality of seeds and substrate difference among tests. There was a high incidence of fungus Alternaria sp. (Table 2) in the lots, which, according to Salustiano et al. (2005), causes loss of viability in the initial stand of the development. In the germination test in paper roll, the integument remains associated to the cotyledons, and the pathogens associated with it cause the seed deterioration, since, upon the emergence in soil and sand mixture of the emergence test, the seedling releases the infected integument in the soil (Juliatti et al., 2011). 
Table 1. Results of the characterization of lots of Helianthus annuus L. seeds, of cultivar Embrapa 122, according to moisture content (M), germination (G), first germination counting (FGC), germination speed index (GSI), emergence (E), initial stand (IS) and emergence speed index (ESI).

\begin{tabular}{cccccccc}
\hline Lots & M (\%) & G $(\%)$ & FGC $(\%)$ & GSI & E (\%) & IS (\%) & ESI \\
\hline L1 & $6.45 \mathrm{~A}$ & $72 \mathrm{~A}$ & $45 \mathrm{~A}$ & $37.29 \mathrm{~A}$ & $83 \mathrm{~A}$ & $75 \mathrm{~B}$ & $14.75 \mathrm{~A}$ \\
L2 & $7.27 \mathrm{~A}$ & $80 \mathrm{~A}$ & $49 \mathrm{~A}$ & $37.80 \mathrm{~A}$ & $92 \mathrm{~A}$ & $85 \mathrm{~A}$ & $16.04 \mathrm{~A}$ \\
L3 & $7.17 \mathrm{~A}$ & $75 \mathrm{~A}$ & $47 \mathrm{~A}$ & $37.88 \mathrm{~A}$ & $87 \mathrm{~A}$ & $79 \mathrm{~B}$ & $16.12 \mathrm{~A}$ \\
\hline CV $(\%)$ & 4.20 & 8.23 & 10.28 & 7.15 & 5.17 & 5.33 & 8.87 \\
\hline
\end{tabular}

Means followed by the same letter in the column do not differ by the Scott Knott at $5 \%$ probability.

In the health check (Table 2) were identified, besides Alternaria sp., the fungi Fusarium sp., Aspergillus sp. and Penicillium sp., without any statistical difference among the lots. Gomes et al. (2006) have found the same pathogens for cultivar Embrapa 122 and these are harmful fungi for the quality of sunflower seeds (Grisi et al., 2009).

After 120 minutes of ozonization of the seeds, inferior results were observed in the germination tests and first counting for all lots (Table 3). This reduction can be attributed to phytotoxicity, because this treatment resulted in abnormalities in the root system, affecting the growth of sunflower seedlings.

There was a reduction of moisture content only in the period of 20 minutes of ozonization and only for lot 2 , statistically differing from the other lots. For the other ozonization times, there was no difference among the moisture values of seeds of each lot (Table 3 ).

By the first germination counting data (Table 3) it was observed that the smallest percentages of germination occurred in the control seeds without ozonization, and in the period of 120 minutes. For lot 1, the 60-minute ozonization period showed a percentage of first germination counting as higher than in the other periods of ozonization; for lot 2 the percentage was higher in the 60-minute period, followed by the 20-minute period. As for lot 3, the 20-minute and 60-minute ozonization periods were higher, not differing from each other.
In the periods of 20 minutes of exposure of sunflower seeds to ozone, higher percentage of the first counting for lots 2 and 3 was observed relative to lot 1 , and in the 60-minute ozonization period, superiority of lot 2 was observed in relation to the others. In the control and after 120 minutes of exposure there was no statistical difference among the lots (Table 3).

As for the germination, it was observed that there was no effect of different periods of ozone exposure for lot 1 . As for lot 2 , the germination percentage was higher after 60 minutes of ozonization and, for lot 3 , there was higher germination after 20 minutes and 60 minutes of ozonization compared to the other treatments. Similar results were observed by Violleau et al. (2008) with maize seeds, where there was an increase of germination after 20 minutes of exposure to ozone.

Table 2. Results of the incidence of Fusarium sp. (FUS), Penicillium sp.(PEN), Aspergillus sp.(ASP) and Alternaria sp.(ALT) in the seeds of Helianthus annuus L, cultivar Embrapa 122, in the characterization of the lots.

\begin{tabular}{ccccc}
\hline Lots & FUS (\%) & PEN (\%) & ASP (\%) & ALT (\%) \\
\hline L1 & $76 \mathrm{~A}$ & $53 \mathrm{~A}$ & $67 \mathrm{~A}$ & $71 \mathrm{~A}$ \\
L2 & $74 \mathrm{~A}$ & $35 \mathrm{~A}$ & $56 \mathrm{~A}$ & $74 \mathrm{~A}$ \\
L3 & $83 \mathrm{~A}$ & $50 \mathrm{~A}$ & $60 \mathrm{~A}$ & $73 \mathrm{~A}$ \\
\hline CV (\%) & 22.15 & 42.22 & 30.44 & 20.98 \\
\hline
\end{tabular}

Means followed by the same letter in the column do not differ by the Scott Knott at 5\% probability.

Table 3. Results of moisture content (M), first germination counting (FGC), germination (G) and germination speed index (GSI) of the seed lots of Helianthus annuus L., cultivar Embrapa 122, after different times (minutes) of ozonization.

\begin{tabular}{ccccccccccccc}
\hline \multirow{2}{*}{$\begin{array}{c}\text { Ozonization } \\
\text { time }\end{array}$} & \multicolumn{3}{c}{ M (\%) } & \multicolumn{4}{c}{ FGC (\%) } & \multicolumn{1}{c}{ G (\%) } & GSI \\
\cline { 2 - 13 } & L1 & L2 & L3 & L1 & L2 & L3 & L1 & L2 & L3 & L1 & L2 & L3 \\
\hline 0 & $6.54 \mathrm{Aa}$ & $7.53 \mathrm{Aa}$ & $6.69 \mathrm{Aa}$ & $47 \mathrm{Ab}$ & $53 \mathrm{Ac}$ & $52 \mathrm{Ab}$ & $70 \mathrm{Aa}$ & $77 \mathrm{Ab}$ & $71 \mathrm{Ab}$ & $40.46 \mathrm{Aa}$ & $44.61 \mathrm{Aa}$ & $42.49 \mathrm{Aa}$ \\
20 & $7.52 \mathrm{Aa}$ & $6.17 \mathrm{Ba}$ & $7.72 \mathrm{Aa}$ & $53 \mathrm{Bb}$ & $63 \mathrm{Ab}$ & $60 \mathrm{Aa}$ & $74 \mathrm{Aa}$ & $80 \mathrm{Ab}$ & $75 \mathrm{Aa}$ & $40.68 \mathrm{Aa}$ & $42.55 \mathrm{Aa}$ & $39.17 \mathrm{Ba}$ \\
60 & $7.12 \mathrm{Aa}$ & $6.80 \mathrm{Aa}$ & $7.80 \mathrm{Aa}$ & $61 \mathrm{Ba}$ & $75 \mathrm{Aa}$ & $64 \mathrm{Ba}$ & $77 \mathrm{Ba}$ & $88 \mathrm{Aa}$ & $78 \mathrm{Ba}$ & $39.35 \mathrm{Aa}$ & $43.91 \mathrm{Aa}$ & $42.00 \mathrm{Aa}$ \\
120 & $7.34 \mathrm{Aa}$ & $6.32 \mathrm{Aa}$ & $7.20 \mathrm{Aa}$ & $51 \mathrm{Ab}$ & $51 \mathrm{Ac}$ & $50 \mathrm{Ab}$ & $69 \mathrm{Aa}$ & $73 \mathrm{Ab}$ & $67 \mathrm{Ab}$ & $37.84 \mathrm{Aa}$ & $40.48 \mathrm{Aa}$ & $38.38 \mathrm{Ba}$ \\
\hline $\mathrm{CV}(\%)$ & & 8.43 & & & 8.77 & & & 7.66 & & 5.54 & \\
\hline
\end{tabular}

Means followed by the same lowercase letter in the column and uppercase letter in the row do not differ by the Scott Knott test at $5 \%$ probability. 
In the control periods, 20 minutes and 120 minutes, there was no difference among the percentages of seed germination. After 60 minutes of ozonization it was possible to classify the lots into different groups, as was observed for the data of the first germination counting (Table 3).

Regarding the germination speed index (GSI) (Table 3), the control treatment and the other treatments belong to the same group for all three lots. In studies using chemical treatment for sunflower seeds sterilization, reduction in the germination speed index is observed in the control treatment seeds (Medeiros et al., 2013; Grisi et al., 2009; Gomes et al., 2006). It is observed that in the ozonization times of 20 and 120 minutes, the germination speed index was higher for lots 1 and 2 in relation to lot 3 .

By the results of the vigor tests (Table 4) there was no effect of ozonization time on seedling emergence. In the initial stand test, 120-minute period, lot 2 had higher percentage of normal seedlings compared to the other lots. However, for the same lot, statistical differences after ozonization were not observed. As for the emergence speed index, there were no differences among the lots; however, there was a significant interaction among the ozonization times within lots, with the highest rates for lot 2 occurring in seeds without ozonization, and after 120 minutes of treatment, as well as for untreated lot 3 and after 60 minutes of ozonization. By means of the accelerated aging test, marked reduction in vigor of all lots of sunflower seeds was observed after treatment with ozone. However, only in the seeds without ozonization (control) differences were detected vigor among lots, it is possible to separate the lots 1 and 2 in a group with higher quality than lot 3.

Table 4. Emergence results (E), initial stand (IS), emergence speed index (ESI), accelerated aging (AA), of the lots of the seeds of Helianthus annuus L., cultivar Embrapa 122, after different times (minutes) of ozonization.

\begin{tabular}{|c|c|c|c|c|c|c|c|c|c|c|c|c|}
\hline \multirow{2}{*}{$\begin{array}{l}\text { Ozonization } \\
\text { time }\end{array}$} & \multicolumn{3}{|c|}{ IS (\%) } & \multicolumn{3}{|c|}{ E (\%) } & \multicolumn{3}{|c|}{ ESI } & \multicolumn{3}{|c|}{ AA (\%) } \\
\hline & L1 & $\mathrm{L} 2$ & L3 & L1 & L2 & L3 & L1 & L2 & L3 & L1 & L2 & L3 \\
\hline 0 & $77 \mathrm{Aa}$ & $85 \mathrm{Aa}$ & $78 \mathrm{Aa}$ & $80 \mathrm{Aa}$ & $89 \mathrm{Aa}$ & $86 \mathrm{Aa}$ & $21.52 \mathrm{Aa}$ & $22.86 \mathrm{Aa}$ & $23.28 \mathrm{Aa}$ & $27 \mathrm{Aa}$ & $34 \mathrm{Aa}$ & $20 \mathrm{Ba}$ \\
\hline 20 & $77 \mathrm{Aa}$ & $85 \mathrm{Aa}$ & $79 \mathrm{Aa}$ & $81 \mathrm{Aa}$ & $86 \mathrm{Aa}$ & $82 \mathrm{Aa}$ & 15.19 Aa & $17.43 \mathrm{Ab}$ & $15.45 \mathrm{Ab}$ & $27 \mathrm{Aa}$ & $17 \mathrm{Ab}$ & $21 \mathrm{Aa}$ \\
\hline 60 & $78 \mathrm{Aa}$ & $84 \mathrm{Aa}$ & $83 \mathrm{Aa}$ & $81 \mathrm{Aa}$ & $82 \mathrm{Aa}$ & $88 \mathrm{Aa}$ & $17.73 \mathrm{Aa}$ & $16.59 \mathrm{Ab}$ & $20.25 \mathrm{Aa}$ & $13 \mathrm{Ab}$ & $27 \mathrm{Aa}$ & $8 \mathrm{Ab}$ \\
\hline 120 & $73 \mathrm{Ba}$ & $80 \mathrm{Aa}$ & $75 \mathrm{Ba}$ & $81 \mathrm{Aa}$ & $91 \mathrm{Aa}$ & $84 \mathrm{Aa}$ & $19.00 \mathrm{Aa}$ & $20.67 \mathrm{Aa}$ & $17.83 \mathrm{Ab}$ & $17 \mathrm{Ab}$ & $17 \mathrm{Ab}$ & $10 \mathrm{Ab}$ \\
\hline CV (\%) & & 9.16 & & & 8.18 & & & 17.77 & & & 33.47 & \\
\hline
\end{tabular}

Means followed by the same lowercase letter in the column and uppercase letter in the row do not differ by the Scott Knott test at 5\% probability.

By the results of viability of sunflower seeds obtained in the tetrazolium test (Table 5) there was no statistical difference among lots after the different ozonization periods tested. This fact is positive since one of the desirable traits in seed treatment is that the product used do not affect viability (Machado, 2000). It was observed that for the 60-minute ozonization time there was a differentiation among the lots, lot 2 being higher than lot 1 and lot 3 , and these results are similar to those observed in the germination test (Table 3).

As for the results of the vigorous seeds percentage (Table 5), obtained in the tetrazolium test, there was no statistical difference among the different ozonization periods. Similar results were observed in the data of GSI, emergence, initial stand (Table 4) and viability tetrazolium (Table 5). There was a distinction of lot 2 as the one of greater vigor in the seeds without ozonization (control) and in treatments of 20 minutes and 120 minutes of ozonization. In the treatment of 60 minutes of ozonization there was no statistical difference among lots.

As occurs after the use of chemical fungicides (Grisi et al., 2009), ozone did not reduce the quality of sunflower seeds.
Table 5. Viability and vigor results by the tetrazolium test, in lots of sunflower seeds, cultivar Embrapa 122, in the different times (minutes) of ozonization.

\begin{tabular}{ccccccc}
\hline \multirow{2}{*}{$\begin{array}{c}\text { Ozonization } \\
\text { time }\end{array}$} & \multicolumn{3}{c}{ Viability (\%) } & \multicolumn{3}{c}{ Vigor (\%) } \\
\cline { 2 - 7 } & L1 & L2 & L3 & L1 & L2 & L3 \\
\hline 0 & $80 \mathrm{Aa}$ & $86 \mathrm{Aa}$ & $80 \mathrm{Aa}$ & $58 \mathrm{Ba}$ & $70 \mathrm{Aa}$ & $59 \mathrm{Ba}$ \\
20 & $80 \mathrm{Aa}$ & $87 \mathrm{Aa}$ & $82 \mathrm{Aa}$ & $63 \mathrm{Ba}$ & $72 \mathrm{Aa}$ & $62 \mathrm{Ba}$ \\
60 & $84 \mathrm{Ba}$ & $89 \mathrm{Aa}$ & $83 \mathrm{Ba}$ & $68 \mathrm{Aa}$ & $75 \mathrm{Aa}$ & $66 \mathrm{Aa}$ \\
120 & $80 \mathrm{Aa}$ & $85 \mathrm{Aa}$ & $78 \mathrm{Aa}$ & $64 \mathrm{Ba}$ & $70 \mathrm{Aa}$ & $57 \mathrm{Ba}$ \\
\hline $\mathrm{CV}(\%)$ & \multicolumn{3}{c}{5.08} & & & 9.56 \\
\hline
\end{tabular}

Means followed by the same lowercase letter in the column and uppercase letter in the row do not differ by the Scott Knott test at 5\% probability.

The incidence of Alternaria sp. (Table 6, Figure 2) in all lots was highest in seeds without the treatment and after 20 minutes of ozonization. After 60 minutes and 120 minutes, there was a reduction in the incidence of this fungus, and therefore there was a tendency of reducing the incidence of Alternaria sp. with the increased time of exposure of the seeds to ozone (Figure 2). Only for the time of 60 minutes there was a difference among lots separating them into two groups, and in lots 1 and 3 the 
reduction of the incidence was greater than for lot 2 .

In the assessment of Fusarium sp. (Table 6, Figure 2) there was a higher incidence in the seeds without ozonization and after 20 minutes. The lowest incidence was found after 60 and 120 minutes of ozonization for lot 1 and lot 2 and for lot 3 the lowest incidence was observed only after 120 minutes of ozonization. There was no statistical difference among lots without ozonization and in the 20-minute period of ozonization for incidence of this fungus. After the 60-minute period, the seeds in lots 1 and 2 had a lower incidence of Fusarium sp. and for the 120-minute period, the lowest incidence was observed in lot 1 .

Table 6. Incidence Index of Alternaria sp., Fusarium sp., Aspergillus sp and Penicillium sp., in the seed lots of Helianthus annuus L., cultivar Embrapa 122, due to the times (minutes) of ozonization.

\begin{tabular}{|c|c|c|c|c|c|c|c|c|c|c|c|c|}
\hline \multirow{2}{*}{ Ozonization time } & \multicolumn{3}{|c|}{ Alternaria sp. } & \multicolumn{3}{|c|}{ Fusarium sp. } & \multicolumn{3}{|c|}{ Aspergillus sp } & \multicolumn{3}{|c|}{ Penicillium sp. } \\
\hline & L1 & $\mathrm{L} 2$ & L3 & L1 & L2 & L3 & L1 & L2 & L3 & L1 & L2 & L3 \\
\hline 0 & $75 \mathrm{Aa}$ & $78 \mathrm{Aa}$ & $80 \mathrm{Aa}$ & $96 \mathrm{Aa}$ & $92 \mathrm{Aa}$ & $98 \mathrm{Aa}$ & $73 \mathrm{Aa}$ & $59 \mathrm{Aa}$ & $68 \mathrm{Aa}$ & $64 \mathrm{Aa}$ & $47 \mathrm{Ba}$ & $61 \mathrm{Aa}$ \\
\hline 20 & $71 \mathrm{Aa}$ & $78 \mathrm{Aa}$ & $68 \mathrm{Aa}$ & $94 \mathrm{Aa}$ & $92 \mathrm{Aa}$ & $94 \mathrm{Aa}$ & $65 \mathrm{Aa}$ & $63 \mathrm{Aa}$ & $56 \mathrm{Aa}$ & $53 \mathrm{Ab}$ & $44 \mathrm{Aa}$ & $49 \mathrm{Aa}$ \\
\hline 60 & $40 \mathrm{Bb}$ & $60 \mathrm{Ab}$ & $38 \mathrm{Bb}$ & $74 \mathrm{Bb}$ & $77 \mathrm{Bb}$ & $92 \mathrm{Aa}$ & $34 \mathrm{Ab}$ & $29 \mathrm{Ab}$ & $38 \mathrm{Ab}$ & $25 \mathrm{Ac}$ & $29 \mathrm{Ab}$ & $32 \mathrm{Ac}$ \\
\hline 120 & $42 \mathrm{Ab}$ & $43 \mathrm{Ab}$ & $50 \mathrm{Ab}$ & $49 \mathrm{Bc}$ & $74 \mathrm{Ab}$ & $76 \mathrm{Ab}$ & $45 \mathrm{Ab}$ & $24 \mathrm{Ab}$ & $34 \mathrm{Ab}$ & $23 \mathrm{Ac}$ & $21 \mathrm{Ab}$ & $15 \mathrm{Ad}$ \\
\hline CV (\%) & & 27.13 & & & 16.65 & & & 28.26 & & & 26.57 & \\
\hline
\end{tabular}

Means followed by the same lowercase letter in the column and uppercase letter in the row do not differ by Scott Knott at $5 \%$ probability.
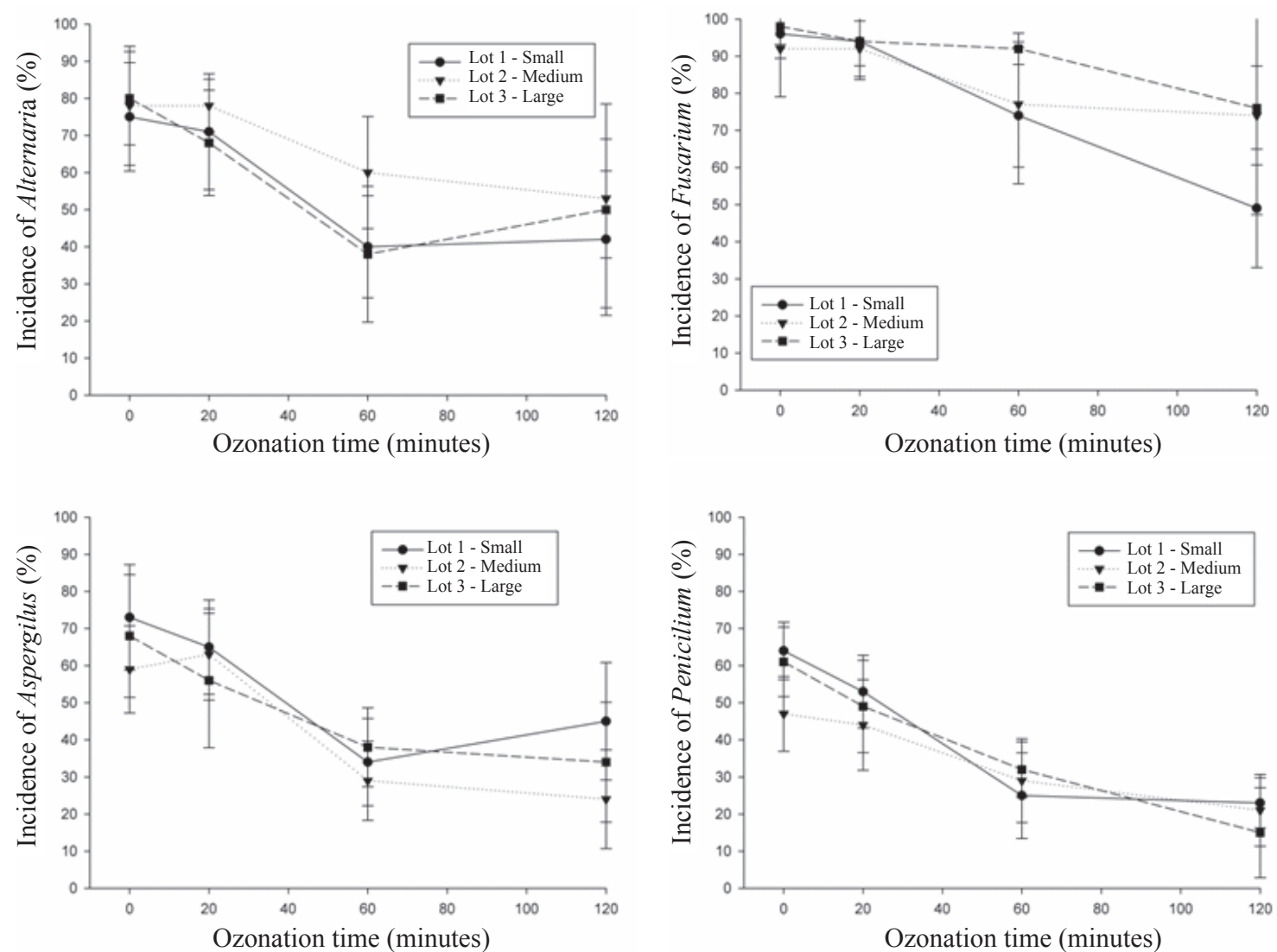

Figure 2. Incidence of the fungi Alternaria sp., Fusarium sp., Aspergillus sp and Penicillium sp. (mean \pm standard deviation) in three seed lots of Helianthus annuus L., cultivar Embrapa 122, due to the times of ozonization.

The incidence of Aspergillus sp. (Table 6, Figure 2) was reduced from 60 minutes of ozonization, as observed for Alternaria sp. and Fusarium sp. According to Freitas-Silva and Venâncio (2008), depending on the ozone concentration injected into cultivated colonies, the inactivation of Aspergillus sp. can reach $80 \%$ to $100 \%$. In all ozonization 
times the lots were similarly ranked.

There was a reduction in the incidence of Penicillium sp. (Table 6, Figure 2) from 20 minutes of ozonization for lots 1 and from 60 minutes for 2 lot. Only without ozonization lot 2 statistically differentiated from the other lots with lower incidence of the fungus. Palou et al. (2002) have obtained similar results reducing the incidence of Penicillium sp. using ozone to sanitize pear fruits after harvest.

In the severity assessments (Table 7, Figure 3) in sunflower seeds that were not treated with ozone, there was a prevalence of the fungus Fusarium sp., followed by Alternaria sp., Aspergillus sp. and Penicillium sp. When subjected to treatment with ozone, reduction of the infestation severity index for all fungi was found.

Table 7. Severity Index of Alternaria sp., Fusarium sp., Aspergillus sp and Penicillium sp., in the lot of seeds of Helianthus annuus L., cultivar Embrapa 122, due to the times (minutes) of ozonization.

\begin{tabular}{|c|c|c|c|c|c|c|c|c|c|c|c|c|}
\hline \multirow{2}{*}{$\begin{array}{l}\text { Ozonization } \\
\text { time }\end{array}$} & \multicolumn{3}{|c|}{ Alternaria sp. } & \multicolumn{3}{|c|}{ Fusarium sp. } & \multicolumn{3}{|c|}{ Aspergillus sp. } & \multicolumn{3}{|c|}{ Penicillium sp. } \\
\hline & L1 & L2 & L3 & L1 & L2 & L3 & L1 & L2 & L3 & L1 & L2 & L3 \\
\hline 0 & $60 \mathrm{Aa}$ & $67 \mathrm{Aa}$ & $65 \mathrm{Aa}$ & $70 \mathrm{Aa}$ & $72 \mathrm{Aa}$ & $79 \mathrm{Aa}$ & $34 \mathrm{Aa}$ & $29 \mathrm{Aa}$ & $33 \mathrm{Aa}$ & $26 \mathrm{Aa}$ & $19 \mathrm{Ba}$ & $26 \mathrm{Aa}$ \\
\hline 20 & $55 \mathrm{Aa}$ & $65 \mathrm{Aa}$ & $55 \mathrm{Aa}$ & $71 \mathrm{Aa}$ & $71 \mathrm{Aa}$ & $78 \mathrm{Aa}$ & $31 \mathrm{Aa}$ & $29 \mathrm{Aa}$ & $25 \mathrm{Ab}$ & $21 \mathrm{Ab}$ & $18 \mathrm{Aa}$ & $20 \mathrm{Ab}$ \\
\hline 60 & $31 \mathrm{Ab}$ & $41 \mathrm{Ab}$ & $28 \mathrm{Ab}$ & $49 \mathrm{Bb}$ & $51 \mathrm{Bb}$ & $71 \mathrm{Aa}$ & $11 \mathrm{Ab}$ & $11 \mathrm{Ab}$ & $13 \mathrm{Ac}$ & $8 \mathrm{Ac}$ & $10 \mathrm{Ab}$ & $11 \mathrm{Ac}$ \\
\hline 120 & $32 \mathrm{Ab}$ & $40 \mathrm{Ab}$ & $40 \mathrm{Ab}$ & $32 \mathrm{Bc}$ & $54 \mathrm{Ab}$ & $56 \mathrm{Ab}$ & $17 \mathrm{Ab}$ & $9 \mathrm{Ab}$ & $12 \mathrm{Ac}$ & $7 \mathrm{Ac}$ & $8 \mathrm{Ab}$ & $5 \mathrm{Ad}$ \\
\hline CV (\%) & & 39.98 & & & 23.96 & & & 33.18 & & & 30.63 & \\
\hline
\end{tabular}

Means followed by the same lowercase letter in the column and uppercase letter in the row do not differ by Scott Knott test at $5 \%$ probability.
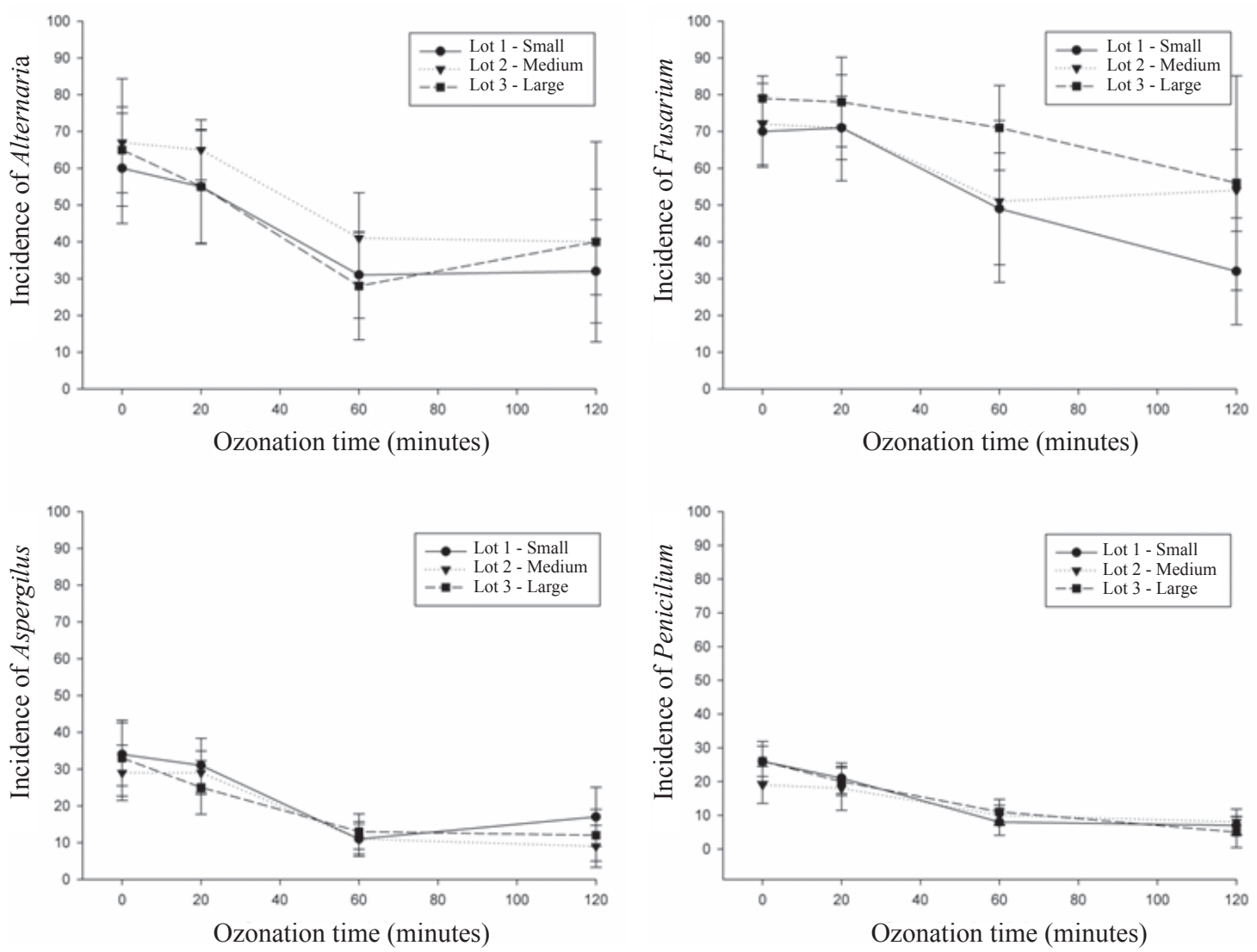

Figure 3. Severity Index of Alternaria sp., Fusarium sp., Aspergillus sp and Penicillium sp. (mean \pm standard deviation) of three seed lots of Helianthus annuus L., cultivar Embrapa 122, due to the times (minutes) of ozonization.

There was a reduction of the infestation severity index (ISI) of Alternaria sp. from 60 minutes of ozonization for all lots of sunflower seeds. In all ozonization times the lots belonged to the same data group. For Fusarium sp., from 60 
minutes of ozonization there was a reduction of the infestation on seeds of lots 1 and 2 and after 120 minutes for lot 3 . There were differences among lots from 60 minutes, when lower infestation severity index was observed for lots 1 and 2, and in the 120-minute period when lot 1 obtained lower ISI compared to the other lots.

For Aspergillus sp. the same tendency of reduction occurred in the evaluation of the incidence of fungus (Table 6 , Figure 2) for lot 1 and lot 2, wherein the reduction was observed from 60 minutes of ozonization. As for lot 3 , the ISI reduction of Aspergillus sp. occurred from 20 minutes of ozonization. All lots corresponding to the control and the tested ozonization treatments were ranked in the same group.

The results of the Penicillium sp severity index observed had the same tendency of incidence results (Table 6, Figure 2) for the same fungus, where ISI was reduced from 20 minutes for lots 1 and 3, and for lot 2 the reduction was observed from 60 minutes of ozonization.

It can be seen that the ozonization for 60 minutes has caused no negative effect on the viability and vigor of sunflower seeds of cultivar Embrapa 122 and has promoted reduction of incidence and severity of all the pathogens found, indicating ozone potential as a sunflower seed sanitizer.

\section{Conclusions}

The treatment of sunflower seeds, cultivar Embrapa 122 with ozone in the concentration of $1741 \mathrm{ppmv}(0.24 \mathrm{~g} / \mathrm{h})$, for 60 minutes, reduces the fungi population of Alternaria sp., Fusarium sp., Aspergillus sp. and Penicillium sp., without affecting their physiological potential.

\section{References}

AGUIAR, R.H.; FANTINATTI, J.B.; GROTH, D.; USBERTI, R. Qualidade física, fisiológica e sanitária de sementes de girassol de diferentes tamanhos. Revista Brasileira de Sementes, v.23, n.1, p.134-139, 2001. http://www. abrates.org.br/revista/artigos/2001/v23n1/artigo19.pdf

AKBAS, M.Y; OZDEMIR, M. Effect of different ozone treatments on aflatoxin degradation and physico-chemical properties of pistachios. Journal of the Science of Food and Agriculture, v.86, n.13, p.2099-2104, 2006. $10.1002 /$ jsfa. 2579

BRASIL. Ministério da Agricultura Pecuária e Abastecimento. Manual de Análise Sanitária de Sementes (Handbook on Seed Health Testing). Ministério da Agricultura, Pecuária e Abastecimento. Brasília: MAPA-ACS, 2009a. 200p. http://www.agricultura.gov.br/arq_editor/file/12261_sementes_-web.pdf

BRASIL. Ministério da Agricultura, Pecuária e Abastecimento. Regras para análise de sementes. Ministério da Agricultura, Pecuária e Abastecimento. Secretaria de Defesa Agropecuária. Brasília: MAPA-ACS, 2009b. 395p. http://www.agricultura.gov.br/arq editor/file/2946 regras analise sementes.pdf
BRASIL. Ministério da Agricultura, Pecuária e Abastecimento. Padrões para produção e comercialização de sementes de girassol. Instrução Normativa $\mathrm{n}^{\circ}$ 45, de 17 de setembro de 2013. Brasília, DF: MAPA/SCS

CAMPANHOLA, C.; BETTIOL, W. Métodos alternativos de controle fitossanitário. Jaguariúna: Embrapa Meio Ambiente, 2003. 279 p.

FERREIRA, D.F. Sisvar: a computer stastistical analysis system. Ciência e Agrotecnologia, v.35, n.6, p.1039-1042, 2011. http://dx.doi.org/10.1590/ S1413-70542011000600001

FREITAS-SILVA, O.; VENÂNCIO, A. Supressão de Aspergillus produtores de aflatoxina e ácido ciclopiazonico por ozônio. Revista Ciência e Vida, v.28, p.128-200, 2008. http://ainfo.cnptia.embrapa.br/digital/bitstream/ item/65812/1/2008-078.pdf

GOMES, D.P.; BRINGEL, J.M.M.; MORAES, M.F.H.; GOMES, J.J.A.; LEITE, R.M.V.B.C. Qualidade fisiológica e sanitária de sementes de girassol produzidas na região de Timon, Maranhão. Summa Phytopathologica, v.32, n.3, p.291-292, 2006. http://dx.doi.org/10.1590/S0100-54052006000300016

GOULART, A.C.P. Detecção e controle químico de Colletotrichum em sementes de soja e algodão. Dourados: Embrapa Agropecuária, 2009. 33p.

GRISI, P.U.; SANTOS, C.M.; FERNANDES, J.J.; SÁ JÚNIOR, A. Qualidade das sementes de girassol tratadas com inseticidas e fungicidas. Bioscience Journal, v.25, n.4, p.28-36, 2009. http://www.seer.ufu.br/index. $\mathrm{php} /$ biosciencejournal/article/viewArticle/6948

JULIATTI, F.C.; DEL BIANCO JUNIOR, R.; MARTINS, J.A.S. Qualidade fisiológica e sanitária de sementes de algodoeiro produzidas nas regiões do Triângulo Mineiro e sul de Goiás. Bioscience Journal, v.27, n.1, p.24-31, 2011. http://www.seer.ufu.br/index.php/biosciencejournal/article/view/7370

KLAPTCHUK, P. Method of destroying seed. World Patent n. WO089078, 7 abr. 2004, 21 out. 2004.

LEITE, R.M.V.B.; BRINGHENTI, A.M.; CASTRO, C. (eds.). Girassol no Brasil. Londrina: Embrapa Soja, 2005. 641p.

LEONARDO, M.S; JARDIM, W.F. Gerador de Ozônio Eletroquímico. Brasil INPI n. PI1101892-5, 2011.

MACHADO, J.C. Padrões de tolerância de patógenos associados às sementes Revisão Anual de Patologia de Plantas, v.2, p. 229-263, 1994.

MACHADO, J.C. Tratamento de sementes no controle de doenças. Lavras: Editora UFLA, 2000. 138p.

MAGUIRE, J.D. Speeds of germination-aid selection and evaluation for seedling emergence and vigor. Crop Science, v.2, p.176-177, 1962.

MCKINNEY, H.H. Influence of soil, temperature and moisture on infection of wheat seedlings by Helminthosporium sativum. Journal of Agricultural Research, v.26, p.195-217, 1923

MEDEIROS, J.G.F.; NETO, A.C.A; MENEZES, N.P.C.; NASCIMENTO, L.C Sanidade e germinação de sementes de Clitoria fairchildiana Howard tratadas com extratos de plantas. Pesquisa Florestal Brasileira, v.33, n.76, p.403-408, 2013. http://pfb.cnpf.embrapa.br/pfb/index.php/pfb/article/viewFile/541/339

MENDEZ, F.; MAIER, D.E.; MASON, L.J.; WOLOSHUK, C.P. Penetration of ozone into columns of stored grains and effects on chemical composition and performance. Journal of Stored Products Research, v.39, p.33-44, 2003. http://www.sciencedirect.com/science/article/pii/S0022474X02000152 
PALOU, L.; CRISOTO, C.H.; SMILANICK, J.L.; ADASKAVEG, J.E.; ZOFFOLI, J.P. Effects of continuous $0.3 \mathrm{ppm}$ ozone exposure on decay development and physical responses of peaches and table grapes in cold storage. Postharvest Biology and Technology, v.24, p.39-48, 2002. http:// handle.nal.usda.gov/10113/19498

PEREIRA, A.M.; FARONI, L.R.D.; SILVA JUNIOR, A.G.; SOUZA, A.H.; PAES, J.L. Viabilidade econômica do gás ozônio como fumigante em grãos de milho armazenados. Engenharia na Agricultura, v.16, n.2, p.144-154, 2008. http://www.seer.ufv.br/seer/index.php/reveng/article/viewFile/12/2

PINTO, A.T.; SCHMIDT, V.; RAIMUNDO, S.A.; RAIHMER, F. Uso de ozônio no controle de fungos em sala de maturação de queijos. Acta Scientiae Veterinariae, v.35, n.3, p.333-337, 2007. http://hdl.handle.net/10183/20606

PONCE, A.R.; BASTIANI, M.I.D.; MINIM, V.P.; VANETTI, M.C.D. Características físico-químicas e microbiológicas de morango minimamente processado. Ciência Tecnologia Alimentos, v.30, n.1, p.113-118, 2010. http:// www.scielo.br/pdf/cta/v30n1/aop 3254.pdf

PORTO, W.S.; CARVALHO, C.G.P.; PINTO, R.J.B. Adaptabilidade e estabilidade como critérios para seleção de genótipos de girassol. Pesquisa Agropecuária Brasileira, v.42, n.4, p.491-499, 2007. http://www.scielo.br/ pdf/pab/v42n4/06.pdf

SALUSTIANO, M.E.; MACHADO, J.C.I.; PITTIS, J.E. Patogenicidade de Alternaria helianthi (Hansf.) e Alternaria zinniae (Pape) ao girassol a partir de sementes. Revista Brasileira de Sementes, v.27, n.1, p.138-143, 2005. http://dx.doi.org/10.1590/S0101-31222005000100017
SERRA, R.; ABRUNHOSA, L.; KOZAKIEWICZ, Z.; VENANCIO, A.; LIMA, N. Use of ozone to reduce molds in a cheese ripening room. Journal of Food Protection, v.66, n.12, p.2355 - 2358, 2003. http://hdl.handle. net/1822/1654

SIMÃO, R.; RODRÍGUEZ, T.D.M. Utilização do ozônio no tratamento pós-colheita do tomate (Lycopersicon esculentum Mill.). Revista de Estudos Sociais, v.2. n.22, p.115-124, 2008. http://periodicoscientificos.ufmt.br/ index.php/res/article/view/246/235

SUDHAKAR, N.; NAGENDRA-PRASAD, D.; MOHAN, N.; HILL, B.; GUNASEKARAN, M.; MURUGESAN, K. Assessing influence of ozone in tomato seed dormancy alleviation. American Journal of Plant Sciences, v.2 n.3, p.443-448, 2011. http://www.scirp.org/journal/PaperInformation. aspx?PaperID $=7608$

VIOLLEAU, F.; HADJEBA, K.; ALBET, J.; CAZALIS, R.; SUREL, O. Increase of corn seeds germination by oxygen and ozone treatment Ozone Science \& Engineering Journal, v.30, n.6, p.418 - 422, 2008 $10.1080 / 01919510802474631$

WU, J.; DOAN, H.; CUENCA, M.A. Investigation of gaseous ozone as an anti-fungal fumigant for stored wheat. Journal of Chemical Technology and Biotechnology, v.81, n.7, p.1288-1293, 2006. http://onlinelibrary.wiley.com/ doi/10.1002/jctb.1550/abstract

YVIN, J.C.; COSTE, C. Method and system for the treatment of seeds and bulbs with ozone. World Patent n. WO1995009523 A1, 4 out. 1994, 13 abr. 1995. 